\section{The China syndrome}

Not everyone interested in English needs to give much thought to Chinese. This statement is so true that it borders on the banal, and a similarly true and banal statement might be: Many people involved with Chinese don't need to give much thought to Engl ish.

It appears, however, that things are changing, and fast, because of the sheer scale on which English is being used and learned in mainland China. Some people (including many Chinese) regard this development as a blessing that throws China open to the world. Some see it simply as a fact of life. But others (whether they are Chinese or not) see it as a major threat to China, to its language(s), and to its cultural traditions.

In our lead article, Jiang Yajun provides the background and detail on this development, and writes (by and large) on the positive side, whereas Niu Qiang and Martin Wolff are more concise and polemical, and strongly negative. My own piece on English as an Asian language, which comes after a report by Terence Pang on English in Hong Kong, was written for a UNESCO magazine in Asia, before I received either the Jiang or the Qiang \& Wolff paper. And it reinforces both. My own fascination at what is happening in Asia is summed up in the following excerpt from that article:

[B] etween them, India and China apparently already account for at least half a billion users and learners of English, a total that (before seeking to bring in equally soft statistics from elsewhere in Asia) could make the continent, in demographic terms, the heaviest 'consumer' of English in the world - and even if this is not so at the time of writing, it is likely to become so in the not far distant future.

Globalization is an overworked term, and has a jargony MBA-ish ring to it, yet it fits both the processes to which it refers and many matters relating to language, notably including developments in China. But, although we devote three articles to the China syndrome in this issue, the rest of the world is not (yet) eclipsed. There are two welcome pieces from Africa (on Cameroon and Malawi), and one each on Greece, the United Arab Emirates, Euro-English, and idioms. There is also, to round off our reporting on the usage of September 11 and the war on terrorism, a photo-montage highlighting that grim short form, 9/ 11.

Tom McArthur

The editorial policy of English Today is to provide a focus or forum for all sorts of news and opinion from around the world. The points of view of individual writers are as a consequence their own, and do not reflect the opinion of the editorial board. In addition, wherever feasible, ET generally leaves unchanged the orthography (normally British or American) and the usage of individual contributors, although the editorial style of the journal itself is that of Cambridge University Press. (c) Cambridge University Press 2003. No contents may be reproduced by any means without the permission of Cambridge University Press.

English Today (ISSN 0266-0784) is a quarterly.

Publisher: Cambridge University Press, The Edinburgh Building, Cambridge CB2 2RU, United Kingdom. Telephone (01223) 312393 Email:

journals_marketing@cup.cam.ac.uk Subscriptions: The 2003 subscription price (excluding VAT) for four issues for libraries and institutions, which includes print and electronic access, is $£ 79.00$ outside of North America;

$£ 32.00$ for individuals; $£ 24$ for students and the retired. The electronic-only price available to institutional subscribers is $f 71.00$. Prices include delivery by air where appropriate. Apply to Jane Crossland at the above address.

Advertising Sales: write to the Advertising Promoter at the above address.

USA, CANADA AND MEXICO:

Publisher: Cambridge University Press, 40 West 20th Street, New York

NY 10011-4211, USA.

Telephone (212) 9243900.

Subscriptions: The 2003 subscription price (excluding VAT) for four issues

for libraries and institutions, which

includes print and electronic access, is $\$ 124.00$ in USA, Canada and Mexico; $\$ 50.00$ for individuals; $£ 37$ for students and the retired. The electronic-only

price available to institutional

subscribers is $\$ 108.00$. Apply to

Marianne Headrick at the above address.

Advertising Sales: write to the

Advertising Coordinator at the above address.

Periodicals postage paid at New York, NY and at additional mailing offices. POSTMASTER: send address changes in

USA, Canada and Mexico to English Today, Cambridge University Press, 110 Midland Avenue, Port Chester, New York, NY 10573-4930, USA.

Japanese prices for institutions are available from Kinokuniya Company Ltd, P.O. Box 55, Chitose, Tokyo 156, Japan.

Letters to the Editor: write to Dr Tom McArthur, Editor, English Today, 22-23 Ventress Farm Court, Cherry Hinton Road, Cambridge CB1 8HD, UK. Tel 01223 245934, Fax 01223241161.

Email: Scotsway@aol.com

Internet access This journal is included in the Cambridge J ournals Online service which can be found at http://uk.cambridge.org/journals. For further information on other Press titles access http://uk.cambridge.org.

Designed and typeset by Peter Ducker. Printed in the United Kingdom at the University Press, Cambridge. 